\title{
Kinetics and reaction pathways of total acid number reduction of cyclopentane carboxylic acid using subcritical methanol
}

\author{
Pradip C. Mandal ${ }^{1,2 *}$, Thasvinya Nagarajan ${ }^{1}$ \\ ${ }^{1}$ Universiti Teknologi PETRONAS, Department of Chemical Engineering, Bandar Seri Iskandar, 31750 Tronoh, Perak, \\ Malaysia \\ ${ }^{2}$ Titas Gas Transmission and Distribution Co. Ltd., 105, Kazi Nazrul Islam Avenue, Kawran Bazar, Dhaka-1215, Bangladesh \\ "Corresponding author: e-mail: pradip.mandal@petronas.com.my,pradipbd2002@yahoo.com
}

\begin{abstract}
Cyclopentane carboxylic acid (CPCA) is a model compound of Naphthenic acids (NAs). This objective of this paper is to discover total acid number (TAN) reduction kinetics and pathways of the reaction between CAPA and subcritical methanol (SubC-MeOH). The experiments were carried out in an autoclave reactor at temperatures of $180-220^{\circ} \mathrm{C}$, a methanol partial pressure (MPP) of $3 \mathrm{MPa}$, reaction times of $0-30 \mathrm{~min}$ and CPCA initial gas phase concentrations of $0.016-0.04 \mathrm{~g} / \mathrm{mL}$. TAN content of the samples were analyzed using ASTM D 974 techniques. The reaction products were identified and quantified with the help of GC/MS and GC-FID respectively. Experimental results reveal that TAN removal kinetics followed first order kinetics with an activation energy of $13.97 \mathrm{kcal} / \mathrm{mol}$ and a pre-exponential factor of $174.21 \mathrm{~s}^{-1}$. Subcritical methanol is able to reduce TAN of CPCA decomposing CPCA into new compounds such as cyclopentane, formaldehyde, methyl acetate and 3-pentanol.
\end{abstract}

Keywords: cyclopentane carboxylic acid, subcritical methanol, total acid number, naphthenic acid, activation energy.

\section{INTRODUCTION}

Naphthenic acids (NAs) present in heavy oil (API gravity between 10 and 20$)^{1}$ are the primary contributor to the acidity of heavy oil ${ }^{2}$. Acidity of petroleum oils is expressed in terms of total acid number (TAN), the amount of potassium hydroxide in milligrams that is needed to neutralize the acids present in one gram of oil ${ }^{3}$. NAs are complex mixtures of alkyl-substituted acyclic and cycloaliphatic carboxylic acids found in hydrocarbon deposits (petroleum, oil sands bitumen, and crude oils) ${ }^{4-6}$. They are thought to have originated from aerobic microbial degradation of petroleum hydrocarbon ${ }^{4}$. They are described by the general chemical formulae, $\mathrm{C}_{\mathrm{n}} \mathrm{H}_{2 \mathrm{n}+\mathrm{z}} \mathrm{O}_{2}$, where $\mathrm{n}$ indicates the carbon number and $\mathrm{z}$ is zero or a negative, even integer that specifies the hydrogen deficiency resulting from ring formation. The absolute value of $\mathrm{z}$ divided by 2 gives the number of rings present in the compounds. The rings can be fused or bridged. Figure 1 shows examples of typical structures of NAs which have a different number of rings ${ }^{5}$. Cyclopentane carboxylic acid (CPCA) is a model compound of NAs whose $z$ value is -2 .

The corrosive NAs can cause many problems such as equipment failures, high maintenance cost, more frequent turnaround, reduce product quality and environmental

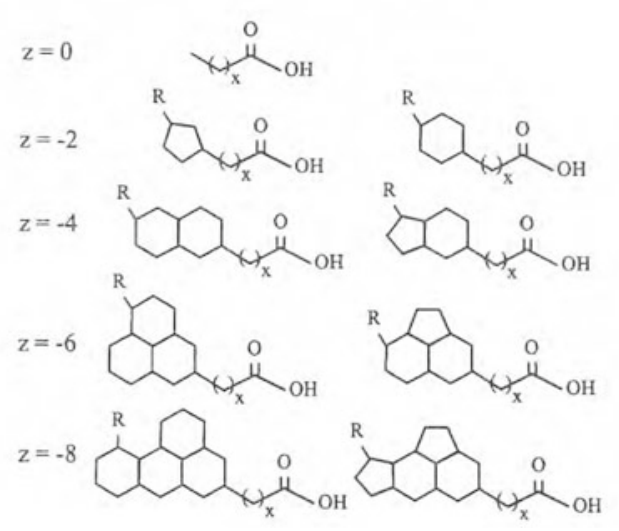

Figure 1. General structure of NAs disposal problems ${ }^{7}$. Research results revealed that corrosion happens at TAN level of $1.5 \mathrm{mg} \mathrm{KOH} / \mathrm{g}$ and above ${ }^{8}$. Apart from that, these NAs may cause emulsification during the refining process making the separation process more complex. As a consequence, crude oils with high TAN content are often marketed at a lower market price ${ }^{9}$. Therefore, the crucial problem that facing by the oil refineries is to find the right method to remove or reduce the acidic substances from petroleum ${ }^{\mathbf{1 0}}$.

There are two ways to increase the value of acidic crude oil such as prevention method and reduction method. The prevention method includes blending, upgrading material and use of metal protective inhibitors. In prevention methods, NA still remains in crude oil which will affect the quality of oil in the earlier stages. So, research is more concentrated on the reduction method. Research results on TAN reduction methods and their disadvantages are summarized in Table 1. Recently, researches are concentrated on reducing acidity of NAs using green processes. Ionic liquids (ILs) and supercritical fluid (SCF) based technologies are widely used in different fields as an environmentally benign process. IL based technology implies high cost. Methanol is simpler form of alcohol having bubble point, $\mathrm{T}_{\mathrm{bp}}=64.6^{\circ} \mathrm{C}$ and $\mathrm{P}_{\mathrm{bp}}=0.1 \mathrm{MPa}$, and critical point, $\mathrm{T}_{\mathrm{c}}=239.45^{\circ} \mathrm{C}$ and $\mathrm{P}_{\mathrm{c}}=8.10 \mathrm{MPa}$. Methanol below its critical point and above its bubble point is considered as subcritical methanol (SubC-MeOH). Methanol above its critical point is known as supercritical methanol (SC-MeOH). In fact, TAN value of NAs need to reduce at temperature less than distillation temperature of crude oil and low pressure for reducing corrosion in production, storage, and transportation of heavy oil. SubC-MeOH can be the best option for acidity reduction at low cost.

The aim of this technical paper is to explore the capability of SubC-MeOH for reducing acidity of CPCA, a model compound of NAs. In addition, TAN removal kinetics and reaction pathways are also explored at temperatures of $180-220^{\circ} \mathrm{C}$, methanol partial pressure (MPP) 
Table 1. Summary of techniques employed in TAN reduction of crude oil

\begin{tabular}{|c|c|c|c|c|c|}
\hline Technique employed & Raw materials & Operating condition & TAN removal [\%] & Disadvantages & References \\
\hline Catalytic destruction & Hydrocarbon oils & $\begin{array}{c}\text { T: } 300-475^{\circ} \mathrm{C} \\
\text { Catalyst: calcium } \\
\text { carbonate containing } \\
\text { about } 1 \% \text { lithium } \\
\text { carbonate }\end{array}$ & Not mentioned & $\begin{array}{c}\text { Catalytic process is not } \\
\text { suitable for treating heavy } \\
\text { oil }\end{array}$ & Rudolf $^{11}, 1941$ \\
\hline $\begin{array}{l}\text { Catalytic } \\
\text { decarboxylation }\end{array}$ & $\begin{array}{c}\text { Texaco crude oil and Acid } \\
\text { mixture (CPCA, cyclohexane } \\
\text { carboxylic acid (CHCA), } \\
\text { benzoic acid (BA), pentyl- } \\
\text { cyclopentane carboxylic acid, } \\
\text { heptyl-benzoic acid) }\end{array}$ & $\begin{array}{c}\text { Texaco crude oil: } \\
\text { T: } 300^{\circ} \mathrm{C}, \mathrm{t}=4 \mathrm{~h} \\
\text { Catalyst: NA-Cat-7 } \\
\text { Acid mixture: } \\
\text { T: } 200^{\circ} \mathrm{C}, \mathrm{t}=4 \mathrm{~h} \\
\text { Catalyst: } \mathrm{NiSiO}_{2} \text {, NA-Cat-1, } \\
\text { NA-Cat-3, NA-Cat-4 }\end{array}$ & $\begin{array}{c}\text { Texaco crude oil: } \\
78.80 \\
\text { Acid mixture: } \\
\text { CPCA conversion: } \\
\text { NiSiO }_{2}: 21.50 \\
\text { NA-Cat- } 1:^{2} 25.50 \\
\text { NA-Cat-3: } 70.80, \\
\text { NA-Cat- } 4: 86.50\end{array}$ & $\begin{array}{c}\text { Catalytic process is not } \\
\text { suitable for treating heavy } \\
\text { oil }\end{array}$ & $\begin{array}{l}\text { Zhang et al. }^{12} \\
2005\end{array}$ \\
\hline Solvent extraction & $\begin{array}{l}\text { Second vacuum fraction } \\
\text { (SVF, a vacuum gas oil } \\
\text { pumped from the second } \\
\text { position in the vacuum } \\
\text { distillation tower of } \\
\text { petroleum) }\end{array}$ & $\begin{array}{c}\text { T: } 60-90^{\circ} \mathrm{C} \\
\text { Additive: an ammonia } \\
\text { solution of ethylene glycol }\end{array}$ & 85 & $\begin{array}{l}\text { Efficiency of the process is } \\
\text { not high and additives are } \\
\text { required }\end{array}$ & $\begin{array}{l}\text { Wang et al. }{ }^{13} \text {, } \\
2006\end{array}$ \\
\hline $\begin{array}{l}\text { Thermal cracking } \\
\text { and catalytic } \\
\text { decarboxylation }\end{array}$ & Bitumen-derived HVGO & $\begin{array}{c}\mathrm{T}: 360^{\circ} \mathrm{C} \\
\text { Catalyst: } \mathrm{CaO}\end{array}$ & 100 & $\begin{array}{c}\text { Catalytic process is not } \\
\text { suitable for treating heavy } \\
\text { oil }\end{array}$ & $\begin{array}{l}\text { Ding et al. } \\
2009\end{array}$ \\
\hline $\begin{array}{l}\text { Catalytic } \\
\text { decarboxylation }\end{array}$ & $\begin{array}{l}\text { Model acid solution includes } \\
\text { five different acids such as } \\
\text { CPCA, CHCA, Cyclohexane } \\
\text { propionic acid (CHPA), BA } \\
\text { and Trans-4-pentyl } \\
\text { cyclohexane carboxylic acid } \\
\text { (TP-CHCA). }\end{array}$ & $\begin{array}{c}\mathrm{T}: 400-800^{\circ} \mathrm{C}, \mathrm{t}: 10 \mathrm{~h} \\
\text { Catalyst: alkali earth metal } \\
\text { oxides were used in this } \\
\text { study, } \mathrm{CM}-\mathrm{MeO}, \mathrm{C}-\mathrm{MeO}, \\
\text { and } \mathrm{CP}-\mathrm{MeO}(\mathrm{Me}=\mathrm{Mg} . \\
\mathrm{Ca}, \mathrm{Sr}, \mathrm{Ba}) .\end{array}$ & Close to 100 & $\begin{array}{c}\text { Catalytic process is not } \\
\text { suitable for treating heavy } \\
\text { oil }\end{array}$ & $\begin{array}{l}\text { Oh et al } \\
2011\end{array}$ \\
\hline Esterification & $\begin{array}{l}\text { Naphthenic acids from } \\
\text { Colombian heavy crude oil }\end{array}$ & $\mathrm{T}: 150-200^{\circ} \mathrm{C}, \mathrm{t}=600 \mathrm{~min}$ & 90.90 & Processing time is long & $\begin{array}{c}\text { Quiroga-Becerra } \\
\text { et al. }{ }^{16}, 2012\end{array}$ \\
\hline Supercritical water & Naphthenic acids & $\begin{aligned} \mathrm{T}: & 400-490^{\circ} \mathrm{C}, \mathrm{P}: 0-45 \\
& \mathrm{MPa}, \mathrm{t}=0-90 \mathrm{~min}\end{aligned}$ & 83 & $\begin{array}{l}\text { High temperatures support } \\
\text { corrosion and require } \\
\text { more investment in the } \\
\text { equipment }\end{array}$ & $\begin{array}{c}\text { Mandal et al. } \\
2012\end{array}$ \\
\hline $\begin{array}{l}\text { Supercritical } \\
\text { methanol }\end{array}$ & Naphthenic acids & $\begin{array}{c}\mathrm{T}: 300-350^{\circ} \mathrm{C}, \mathrm{P}: 10 \mathrm{MPa} \\
\mathrm{t}=0-60 \mathrm{~min}\end{array}$ & 96.87 & $\begin{array}{l}\text { High temperatures support } \\
\text { corrosion and require } \\
\text { more investment in the } \\
\text { equipment }\end{array}$ & $\begin{array}{c}\text { Mandal et al. }{ }^{3}, \\
2013\end{array}$ \\
\hline $\begin{array}{l}\text { lonic liquid (IL) } \\
\text { based extraction }\end{array}$ & Doba crude oil & $\begin{array}{c}\mathrm{T}: 25-90^{\circ} \mathrm{C} \\
\text { t: } 20 \mathrm{~min} \\
\text { IL: tetraalkylammonium } \\
\text { and tetraalkylphosphonium } \\
\text { amino acid based ILs }\end{array}$ & 94.97 & $\begin{array}{l}\mathrm{IL} \text { is costly and separation } \\
\text { of IL is also difficult. }\end{array}$ & $\begin{array}{c}\text { Anderson et al. } \\
17,2013\end{array}$ \\
\hline Esterification & Crude oil & 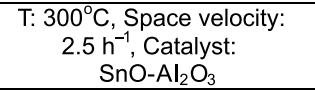 & 82.14 & $\begin{array}{c}\text { Catalytic process is not } \\
\text { suitable for treating heavy } \\
\text { oil }\end{array}$ & $\begin{array}{l}\text { Wang et al. } \\
2014\end{array}$ \\
\hline $\begin{array}{l}\text { Catalytic } \\
\text { decomposition }\end{array}$ & China crude oil & $\begin{array}{c}\mathrm{T}: 330^{\circ} \mathrm{C} \\
\text { Catalyst: } \mathrm{Mg}-\mathrm{Al} \\
\text { hydrotalcite/ } \mathrm{Y}-\mathrm{Al} 2 \mathrm{O} 3\end{array}$ & 80 & $\begin{array}{c}\text { Catalytic process is not } \\
\text { suitable for treating heavy } \\
\text { oil }\end{array}$ & $\begin{array}{l}\text { Wang et al. } \\
2014\end{array}$ \\
\hline $\begin{array}{l}\text { Catalytic } \\
\text { decomposition }\end{array}$ & Korean crude oil & $\begin{array}{c}\text { T: } 35-40^{\circ} \mathrm{C} \\
\text { Catalyst: } \mathrm{Cu} / \mathrm{Ce} \\
(10: 90) / \mathrm{Al} 2 \mathrm{O} 3 \\
\text { Reagent: } 4 \% \text { ammonia } \\
\text { solution in polyethylene } \\
\text { glycol }\end{array}$ & 93.3 & $\begin{array}{l}\text { Catalytic process is not } \\
\text { suitable for treating heavy } \\
\text { oil }\end{array}$ & $\begin{array}{l}\text { Shukri et al. }{ }^{9}, \\
2015\end{array}$ \\
\hline $\begin{array}{l}\text { Catalytic } \\
\text { decarboxylation }\end{array}$ & High-acidity crude oil & $\begin{array}{c}\text { T: } 300-350^{\circ} \mathrm{C} \\
\text { t: } 4 \mathrm{~h} \\
\text { Catalyst: steel slag }\end{array}$ & 43.50 & $\begin{array}{c}\text { Catalytic process is not } \\
\text { suitable for treating heavy } \\
\text { oil. }\end{array}$ & $\begin{array}{l}\text { Dias et al. }{ }^{18}, \\
2015\end{array}$ \\
\hline IL based extraction & Naphthenic acids & $\begin{array}{c}\mathrm{T}: 30^{\circ} \mathrm{C}, \mathrm{t}: 1 \mathrm{~h} \\
\mathrm{IL}: \mathrm{N} \text {-alkyl imidazolium } \\
\text { ionic liquids with highly } \\
\text { alkaline phenolate anions } \\
\text { IL/ oil: } 0.01-0.09\end{array}$ & 100 & $\begin{array}{l}\text { IL is costly and separation } \\
\text { of IL is also difficult }\end{array}$ & $\begin{array}{c}\text { Shah et al. }{ }^{19} \text {, } \\
2016\end{array}$ \\
\hline
\end{tabular}

of $3 \mathrm{MPa}$, reaction temperatures of 0-30 min and CPCA initial gas phase concentrations of $0.016-0.04 \mathrm{~g} / \mathrm{mL}$.

\section{METHODOLOGY}

\section{Material used}

CPCA $\left(\mathrm{C}_{6} \mathrm{H}_{10} \mathrm{O}_{2}\right)$ was chosen as a model compound of NAs in this study. It has one cyclopentyl group with one carboxyl group where $\mathrm{z}=-2$ and $\mathrm{n}=6$. This compound (purity: 99\%) was purchased from Sigma-Aldrich and was used without further treatment. It is almost a colorless liquid having molecular weight $114.14 \mathrm{~g} / \mathrm{mol}$, boiling point $216^{\circ} \mathrm{C}$, and density $1.053 \mathrm{~g} / \mathrm{mL}$ at a temperature of $25^{\circ} \mathrm{C}$. Other reagents, toluene, 2-propanol, potassium hydroxide, and phenolphthalein were obtained from EMD Corporation and were used without further treatment. The mixture of toluene, and 2-propanol at a ratio of 1:1 was used as solvent for collecting the samples and determining TAN.

\section{Equipment}

All experiments were performed in $25 \mathrm{ml}$ autoclave reactor fabricated by Shanghai Yanzheng Experiment Instrument Co., Ltd., China for maximum temperature of $230^{\circ} \mathrm{C}$ and pressure of $3 \mathrm{MPa}$ (gauge). The reactor is a stainless steel structure, durable and gas-tight. Inner 
chamber of the reactor is made from polytetrafluoroethylene (PTFE) to minimize corrosion.

\section{Experimental procedure}

Approximately $0.40-1.0 \mathrm{~g}$ of CPCA and $0.72-0.87 \mathrm{~g}$ (approximately $0.9-1.1 \mathrm{~mL}$ ) of methanol were charged into the autoclave reactor. The amount of loaded methanol was maintained to control MPP at constant reactor volume and reaction temperature. The well-known Peng-Robinson equation of state was exercised to compute the amount of methanol by fixing the temperature and the MPP. A precise amount of methanol was charged into the reactor for the time of experiments. The reactor was then loaded into a furnace that was preheated to the planned temperature. After a specific reaction time, the reactor was removed from the furnace and kept it in a water bath by allowing sufficient time to cool the reactor at room temperature. Finally, the products were collected in sample bottles by washing the reactor interior at least three times with the solvent.

\section{Analytical procedure}

Mandal et al. ${ }^{3,7}$ disclosed that American Society for Testing Materials (ASTM) D 974 has sufficient accuracy for evaluating TAN value. This method was used in this study for evaluating TAN value. In this process, a mixture of toluene and 2-propanol in 1:1 ratio was used as solvent and phenolphthalein was used as an indicator for detecting end point. A precise amount of recently prepared $0.05 \mathrm{~mol} / \mathrm{L}$ standard potassium hydroxide solution was utilized as a titrant. The analysis was carried out carefully to achieve low TAN value. The following terms are used in this study:

Titration was conducted to estimate the acidity of NAs. TAN was calculated by identifying the amount of potassium hydroxide needed to neutralize $1 \mathrm{~g}$ of CPCA using the following equation:

TAN $\left(\frac{\mathrm{mg} \mathrm{KOH}}{\mathrm{g} \mathrm{CPCA}}\right)=\left[\frac{\mathrm{V}_{\mathrm{KOH}} \times \mathrm{N}_{\mathrm{KOH}} \times 56.10}{\mathrm{~W}_{\mathrm{CPCA}, 0}}\right]$

where $\mathrm{V}_{\mathrm{KOH}}$ is volume of $\mathrm{KOH}$ in $\mathrm{ml}, \mathrm{N}_{\mathrm{KOH}}$ is the concentration of $\mathrm{KOH}$ in $\mathrm{mmol} / \mathrm{ml}$, and is the amount of NA in $g$.

TAN reduction was calculated in order to identify the extent of reduction of acidity in CPCA using the equation shown below:

TAN reduction $(\%)=\frac{\text { TAN }_{0}-\mathrm{TAN}_{\mathrm{t}}}{\mathrm{TAN}_{0}} \times 100$

where $\mathrm{TAN}_{0}$ is the initial TAN in loaded CPCA and is the TAN at reaction time, $t$.

The reaction products were also analysed using gas chromatography-mass spectrometry (GC/MS) method for identifying reaction products. The column, BPX5 non polar and low bleed capillary column, $30 \mathrm{~m}$ long by 0.25 $\mathrm{mm}$ diameter was used. The samples were diluted by adding methylene chloride before charging the samples in GC/MS analyser at a specified temperature program. In addition, the reaction products were quantified using Gas chromatography - flame ionization detector (GC-FID) using same column and temperature program.
All experiments were carried out triple. The error margin of the achieved data was less than $4 \%$ with 95\% confident.

\section{RESULTS AND DISCUSSION}

\section{TAN reduction}

Mandal et al. ${ }^{7}$ discovered that $\mathrm{SC}-\mathrm{MeOH}$ have capability of reducing approximately $100 \%$ TAN of NAs at a temperature of $350^{\circ} \mathrm{C}$ and a MPP of $10 \mathrm{MPa}$. But this condition is very high to treat heavy oil for reducing corrosion as a pre-treatment. Quiroga-Becerra et al. ${ }^{16}$ discovered that approximately 95\% TAN was reduced from NAs obtained from Colombian heavy crude oil at temperature of $250^{\circ} \mathrm{C}$, reaction time of $600 \mathrm{~min}$, and a methanol to acid ratio of $20: 1$. It is no doubt that SubC-MeOH can reduce acidity of NAs. To observe the capability of SubC-MeOH for TAN reduction of CPCA, approximately eighteen experiments were performed at temperatures of $180-220^{\circ} \mathrm{C}$, a CPCA gas phase concentration of $0.032 \mathrm{~g} / \mathrm{mL}$, and reaction times of $0-30 \mathrm{~min}$. CPCA used in this study had an initial TAN value 545.5 $\mathrm{mg} \mathrm{KOH} / \mathrm{g}$ CPCA. Figure 2 shows that TAN removal of CPCA was increasing with increasing reaction temperature and time at a specific MPP. Approximately $17.56 \%$ TAN was removed at a temperature of $220^{\circ} \mathrm{C}$, a MPP of $3 \mathrm{MPa}$, a reaction time of $30 \mathrm{~min}$. SubC-MeOH is a good solvent for CPCA. During reaction, CPCA and methanol was mixed properly with increasing temperature and thus increase the collisions between them to increase the rate of reaction.

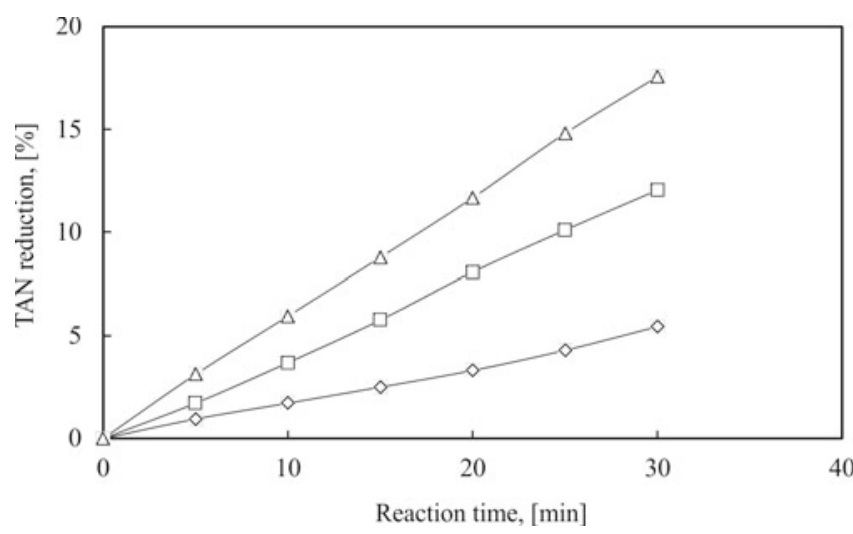

Figure 2. Variation of TAN reduction at a function of temperature and reaction time (Symbol: $\downarrow$, at temperature of $180^{\circ} \mathrm{C} ; \square$, at temperature of $200^{\circ} \mathrm{C} ; \Delta$, at temperature of $220^{\circ} \mathrm{C}$ )

\section{TAN reduction kinetics}

Reaction kinetics is very important to design chemical reactor. Mandal et al. ${ }^{3}$ shows that TAN reduction kinetics of the reaction of NA and SC-MeOH follow first order kinetics. Besides that reaction between some organic acids and fatty alcohol showed first order kinetics with respect to acid $^{20}$. On the other hand, Wang et al. ${ }^{13}$ proves that reaction kinetics of esterification reaction between NA and methanol with and without $\mathrm{SnO}$ catalyst follows second order kinetics. Likewise esterification reaction between oleic acid and methanol under the pressure also shows the second order kinetics ${ }^{21}$. Similarly, the kinetics of the esterification process of NAs in Colombian heavy crude oil using methanol without adding any catalyst 
follows second order kinetics ${ }^{16}$. To discover the reaction order of the reaction between CPCA and SubC-MeOH, a plot of $-\ln (1-X)$ where $X$ denotes fraction of TAN reduction versus reaction time is plotted (Fig. 3). Each set of data give straight line which obtained with the least square method pass almost exactly through the origin indicating first order kinetics with respect to TAN removal. The experiments were conducted by changing the initial concentration of CPCA at a temperature of $220^{\circ} \mathrm{C}$ and a MPP of $3 \mathrm{MPa}$, indicating that reaction rate is independent on initial CPCA concentration. The reaction kinetics analysis of this study was tested and evaluated to a maximum of $17.56 \%$ TAN removal as kinetics data were more compatible with first order kinetics at this extent ${ }^{22}$. An Arrhenius type temperature dependency acidity removal rate constant is presented in Figure 4. By exploring this plot the activation energy and pre-exponential factor of the said reaction was discovered and the respective values were $13.97 \mathrm{kcal} /$ mol and $174.21 \mathrm{~s}^{-1}$. Thus the Arrhenius equation can be rewritten as:

$\mathrm{k}_{\text {SubC }-\mathrm{MeOH}}=174.21 \mathrm{e}^{\frac{-13.97}{\mathrm{RT}}}$

The activation energy for reaction between $\mathrm{SC}-\mathrm{MeOH}$ and NAs is $5.78 \mathrm{kcal} / \mathrm{mol}^{3}$. Wang et al. in $2006^{13}$ obtained activation energy of $36.74 \mathrm{kcal} / \mathrm{mol}$ and $24.89 \mathrm{kcal} / \mathrm{mol}$ for esterification reaction between methanol and NA with $1 \mathrm{wt} . \% \mathrm{SnO}$ catalyst and without catalyst respectively. In addition, the activation energy for the esterification reaction of NAs in Colombian heavy crude oil ${ }^{16}$ and methanol at temperatures of $150-250^{\circ} \mathrm{C}$ is $17.27 \mathrm{kcal} /$ mol. Thus, SubC-MeOH requires higher energy than $\mathrm{SC}-\mathrm{MeOH}$, and lower energy than the other methods

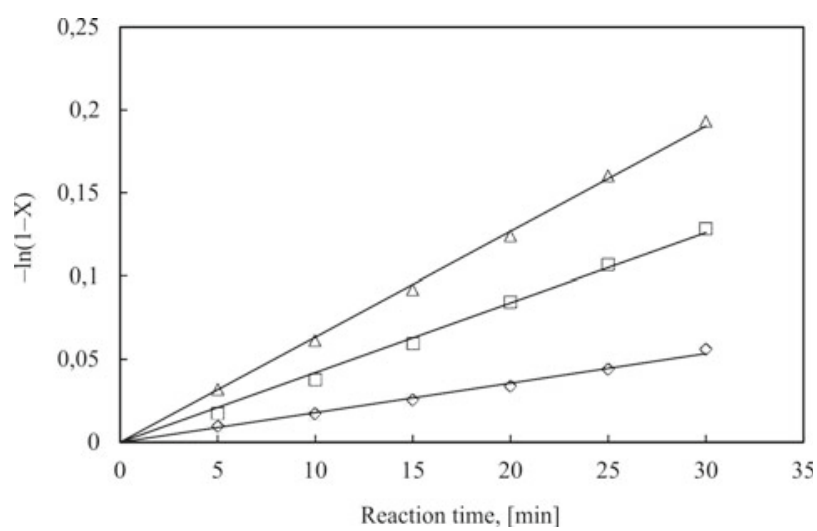

Figure 3. TAN reduction kinetics plot (Symbol: $\downarrow$, at temperature of $180^{\circ} \mathrm{C} ; \square$, at temperature of $200^{\circ} \mathrm{C} ; \Delta$, at temperature of $220^{\circ} \mathrm{C}$ )

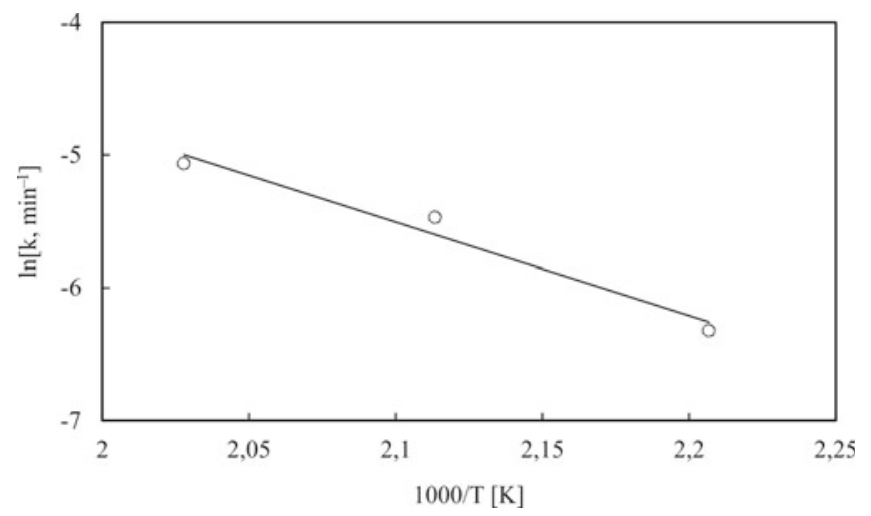

Figure 4. Arrhenius plot presented by Wang et al. and Quiroga-Becerra et al. The methanol in this reaction is behaved not only as reaction medium but also as reactant.

\section{Reaction pathways}

CPCA was decomposed into other non-acidic compounds by reacting with methanol at subcritical condition. Figure 5 depicts that concentration of CPCA was decreasing with increasing reaction temperature and time. Initial CPCA concentration was $0.0324 \mathrm{~g} / \mathrm{mL}$. This value was decreased to $0.0256 \mathrm{~g} / \mathrm{mL}$ at a temperature of $220^{\circ} \mathrm{C}$, a MPP of $3 \mathrm{MPa}$, a reaction time of $30 \mathrm{~min}$. Esterification reaction is a well-known process of TAN reduction of crude oil. But at the crude oil refinement temperature some esters can decompose into organic acids and create problems on distillation column and product quality as the structure of the ester will determine its thermal stability. Mandal et al. ${ }^{3}$ in 2013 have done experiments using NA and SC-MeOH and have identified esters (like, nonanoic acid, methyl ester; decanoic acid, methyl ester and so on), saturated alkylbenzenes (like, heptylbenzene), and alkanes (like, decosane) using GC-MS that were not present in NA samples. Current study revealed that non catalytic SubC-MeOH process reacted with CPCA and produced not only ester but also cyclopentane, formaldehyde and alcohol (Fig. 6). The reaction products were quantified using GC-FID and the results are presented in Table 2. GC/MS and GC-FID analysis results show that the reaction products contains cyclopentane, formaldehyde and 2-tridecanone at temperature of $180^{\circ} \mathrm{C}$, reaction time of $15 \mathrm{~min}$. Calvert et al. ${ }^{23}$

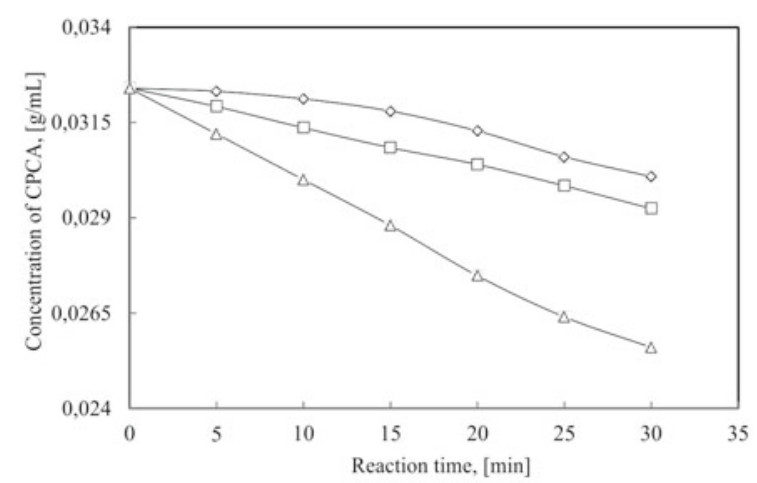

Figure 5. Variation of CPCA concentration at a function of temperature and reaction time (Symbol: $\nabla$, at temperature of $180^{\circ} \mathrm{C} ; \square$, at temperature of $200^{\circ} \mathrm{C}$; $\Delta$, at temperature of $220^{\circ} \mathrm{C}$ )

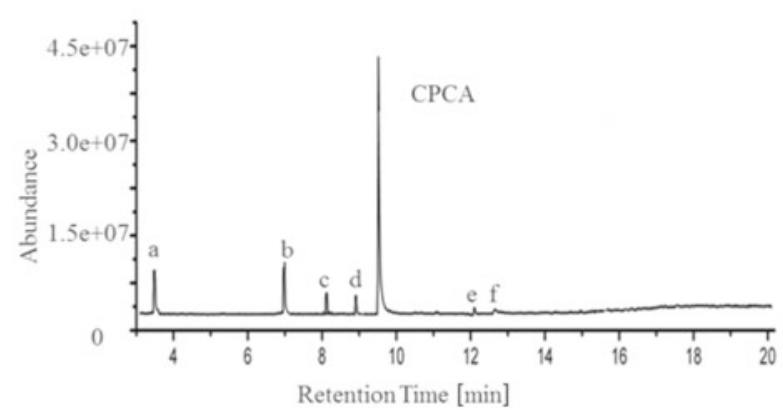

Figure 6. GC-MS chromatogram for CPCA at a temperature of $220^{\circ} \mathrm{C}$, MPP of $3 \mathrm{MPa}$ (a. Formaldehyde; b. Cyclopentane; c. Acetic acid methyl ester; d. 3-pentanol; e. 2-tridecanone; f. Octadecanoic acid) 
Table 2. Product distribution at different temperatures

\begin{tabular}{|c|c|c|c|c|c|c|}
\hline Temperature $\left[{ }^{\circ} \mathrm{C}\right]$ & \multicolumn{6}{|c|}{180} \\
\hline Reaction time [min[ & 5 & 10 & 15 & 20 & 25 & 30 \\
\hline MPP [MPa] & 3 & & & & & \\
\hline Compounds & \multicolumn{6}{|c|}{ Molar yield [\%] / Conversion [\%] } \\
\hline Conversion & - & - & 2.5 & 3.31 & 4.29 & 5.44 \\
\hline CPCA & - & - & 97.5 & 96.69 & 95.71 & 94.56 \\
\hline Cyclopentane & - & - & 0.84 & 1.13 & 1.5 & 1.8 \\
\hline Formaldehyde & - & - & 0.65 & 0.82 & 1.1 & 1.4 \\
\hline 2-tridecanone & - & - & 0.68 & 0.64 & 0.55 & 0.42 \\
\hline Octadecanoic acid & - & - & - & 0.27 & 0.18 & - \\
\hline 3-pentanol & - & - & - & - & 0.25 & 0.34 \\
\hline Acetic acid methyl ester & - & - & - & - & 0.39 & 0.55 \\
\hline Temperature $\left[{ }^{\circ} \mathrm{C}\right]$ & \multicolumn{6}{|c|}{200} \\
\hline Reaction time [min] & 5 & 10 & 15 & 20 & 25 & 30 \\
\hline MPP [MPa] & \multicolumn{6}{|c|}{3} \\
\hline Compounds & \multicolumn{6}{|c|}{ Molar yield [\%] / Conversion [\%] } \\
\hline Conversion & - & 3.69 & 5.76 & 7.97 & 9.99 & 11.94 \\
\hline CPCA & - & 96.31 & 94.24 & 92.03 & 90.01 & 88.06 \\
\hline Cyclopentane & - & 1.14 & 1.62 & 2.3 & 2.9 & 3.5 \\
\hline Formaldehyde & - & 0.73 & 1.11 & 1.5 & 2.1 & 2.6 \\
\hline 2-tridecanone & - & 1.18 & 1.05 & 0.85 & 0.68 & 0.51 \\
\hline Octadecanoic acid & - & - & 0.42 & 0.27 & 0.18 & - \\
\hline 3-pentanol & - & - & 0.65 & 1.1 & 1.7 & 2.2 \\
\hline Acetic acid methyl ester & - & - & 0.85 & 1.6 & 2.1 & 2.7 \\
\hline Temperature $\left[{ }^{\circ} \mathrm{C}\right]$ & \multicolumn{6}{|c|}{220} \\
\hline Reaction time [min] & 5 & 10 & 15 & 20 & 25 & 30 \\
\hline MPP [MPa] & \multicolumn{6}{|c|}{3} \\
\hline Compounds & \multicolumn{6}{|c|}{ Molar yield [\%] / Conversion [\%] } \\
\hline Conversion & 3.22 & 5.85 & 8.68 & 11.57 & 14.68 & 17.08 \\
\hline CPCA & 96.78 & 94.15 & 91.32 & 88.43 & 85.32 & 82.92 \\
\hline Cyclopentane & 1.02 & 2 & 3 & 4 & 4.8 & 5.5 \\
\hline Formaldehyde & 0.75 & 1.2 & 1.7 & 2.5 & 3.3 & 4.2 \\
\hline 2-tridecanone & 0.78 & 1.25 & 1.5 & 1.2 & 1.01 & 0.98 \\
\hline Octadecanoic acid & 0.5 & 0.42 & 0.32 & 0.3 & 0.2 & 0.15 \\
\hline 3-pentanol & - & 0.4 & 0.8 & 1.5 & 2 & 2.5 \\
\hline Acetic acid methyl ester & - & 0.5 & 1 & 1.5 & 2.5 & 3.5 \\
\hline
\end{tabular}

revealed that formaldehyde vapor (boiling point $-19^{\circ} \mathrm{C}$ ) is relatively stable with respect to thermal decomposition below $400^{\circ} \mathrm{C}$. Cyclopentane is also stable below $240^{\circ} \mathrm{C}^{\mathbf{2 4}}$. Table 2 depicts that a new product, octadecanoic acid, was formed at a temperature of $180^{\circ} \mathrm{C}$, reaction time of $20 \mathrm{~min}$; a temperature of $200^{\circ} \mathrm{C}$, a reaction time of 15 min and a temperature $220^{\circ} \mathrm{C}$, reaction time of $5 \mathrm{~min}$ indicating that octadecanoic acid was the secondary product. Octadecanoic acid can be formed from 2-tridecanone as the yield of 2-tridecanone was increased first and then decreased. Two new products, 3-pentanol and acetic acid methyl ester, were formed at a temperature of $180^{\circ} \mathrm{C}$, a reaction time of $25 \mathrm{~min}$; a temperature of $200^{\circ} \mathrm{C}$, a reaction time of $15 \mathrm{~min}$ and a temperature of $220^{\circ} \mathrm{C}$, a reaction time of $10 \mathrm{~min}$ along with cyclopentane and formaldehyde. The yield of octadecanoic acid was decreasing with increasing reaction time and the yields of 3-pentanol and acetic acid methyl ester were increasing with increasing reaction time. This result indicated that 3-pentanol and acetic acid methyl ester were secondary products which can be produced from octadecanoic acid. Carboxylic acid reacts with alcohol under acid catalyst and produce ester through esterification reaction. Based on the above discussion the estimated reaction pathways of the reaction between CPCA and SubC-MeOH is presented in Figure 7.

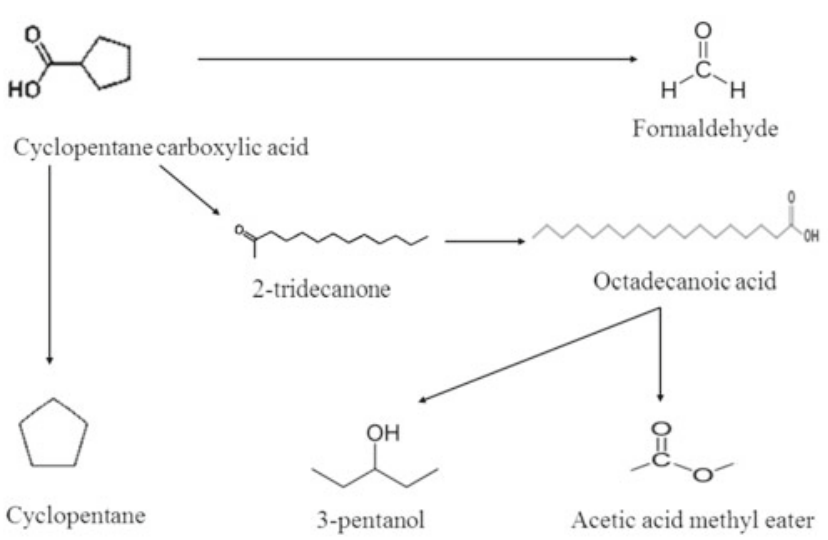

Figure 7. The estimated reaction pathways of the reaction between CPCA and SubC-MeOH

\section{CONCLUSIONS}

The capability of SubC-MeOH on TAN reduction of CPCA was explored in this study. TAN reduction was affected by the reaction temperature and treatment time and was increasing with increasing reaction time and temperature. SubC-MeOH reduced approximately $17.56 \%$ TAN of CPCA at a temperature of $220^{\circ} \mathrm{C}$, a MPP of $3 \mathrm{MPa}$, a reaction time of $30 \mathrm{~min}$, and a CPCA concentration of $0.032 \mathrm{~g} / \mathrm{mL}$. The kinetics of TAN reduction of CPCA using SubC-MeOH without the addition of catalyst at specified reaction conditions was adjusted to a first order rate law with respect to the TAN reduction of CPCA. Esterification reaction, and cyclopentane, formaldehyde and alcohol formation reactions were involved in the reaction mechanisms of TAN 
removal under experimental conditions. The calculated activation energy of the reaction is $13.97 \mathrm{kcal} / \mathrm{mol}$. This value is lower than the reaction of methanol with NAs of Colombian crude oil at temperatures of $150-250^{\circ} \mathrm{C}$.

\section{ACKNOWLEDGMENT}

This work was supported by the Short Term Internal Research Fund (STIRF), Universiti Teknologi PETRONAS, Malaysia.

\section{LITERATURE CITED}

1. Hardacre, C., Goodrich, P. \& Anderson, K. (2012). Processing for removing organic acids from crude oil and crude oil distillates. U.S. Pat. No. 20120132564 A1.

2. Wang, Y.Z., Li, J.Y., Sun, X.Y., Duan, H.L., Song, C.M., Zhang, M.M. \& Liu, Y.P. (2014). Removal of naphthenic acids from crude oils by fixed-bed catalytic esterification. Fuel 116, 723-728. DOI: 10.1016/J.FUEL.2013.08.047.

3. Mandal, P.C., Wahyudiono, Sasaki, M. \& Goto, M. (2013). Non-catalytic reduction of total acid number (TAN) of naphthenic acids (NAs) using supercritical methanol. Fuel Process. Technol. 106, 641-644. DOI: 10.1016/J.FUPROC.2012.09.058.

4. Clemente, J.S. \& Fedorak, P.M. (2005). A review of the occurance, analyses, toxicity, and biodegradation of naphthenic acids. Chemosphere 60(5), 585-600. DOI: 10.1016/J.CHEMOSPHERE.2005.02.065.

5. Headley, J.V. \& McMartin, D.W. (2004). A review of the occurrence and fate of naphthenic acids in aquatic environments. J. Environ. Sci. Health A 39(8), 1989-2010. DOI: 10.1081/ESE-120039370.

6. Scott, A.C., MacKinnon, M.D. \& Fedork, P.M. (2005). Naphthenic acids in Athabasca oil sands tailing waters are less biodegradable than commercial naphthenic acids. Environ. Sci. Technol. 39, 8388-8394. DOI: 10.1021/es051003k.

7. Mandal, P.C., Wahyudiono, Sasaki, M. \& Goto, M. (2012). Reduction of total acid number (TAN) of naphthenic acid (NA) using supercritical water for reducing corrosion problems of oil refineries. Fuel 94, 620-623. DOI: 10.1016/J.FUEL.2011.11.008.

8. Kane, R. \& Cayard, M. (2002). A comprehensive study on naphthenic acid corrosion. Corrosion, NACE International, Houston, USA, Paper No. 02555, 1-16. http://www.icorr.net/ wp-content/uploads/2011/01/napthenic_corrosion.pdf

9. Shukri, N.M., Bakar, W.A., Jaafar, J. \& Majid, Z.A. (2015). Removal of naphthenic acids from high acidity Korean crude oil utilizing catalytic deacidification method. J. Ind. Eng. Chem. 28, 110-116. DOI:10.1016/J.JIEC.2015.02.005.

10. Wang, Y.Z., Zhong, D.L., Duan, H.L., Song, C.M., Han, X.T. \& Ma, X.R. (2014). Removal of naphthenic acids from crude oils by catalytic decomposition using $\mathrm{Mg}-\mathrm{Al}$ hydrotalcite $/ \gamma-\mathrm{Al}_{2} \mathrm{O}_{3}$ as a catalyst. Fuel $134,499-504$. DOI: 10.1016/J.FUEL.2014.06.026.

11. Rudolf, M.F. (1941). Process for removing naphthenic acids from hydrocarbon oils. U.S. Pat. No. US 2227811 A.

12. Zhang, A., Ma, Q., Wang, K., Tang, Y. \& Goddard, W.A. (2005). Improved processes to remove naphthenic acids. Final Technical Report, California Institute of Technology, Pasadena, CA, DE-FC26-02NT15383, 1-96. Retrieved December 30, 2015, from Research Gate. DOI: 10.2172/825290.

13. Wang, Y., Chu, Z., Qiu, B., Liu, C. \& Zhang, Y. (2006). Removal of naphthenic acids from a vacuum fraction oil with an ammonia solution of ethylene glycol. Fuel 85(17-18), 2489-2493. DOI: 10.1016/J.FUEL.2006.04.032.

14. Ding, L., Rahimi, P., Hawkins, R., Bhatt, S. \& Shi, Y. (2009). Naphthenic acid removal from heavy oils on alkaline earth-metal oxides and $\mathrm{ZnO}$ Catalyst. Appl. Catal. A-Gen. 371(1-2), 121-130. DOI: 10.1016/J.APCATA.2009.09.040.
15. Oh, H.Y., Park, J.H., Rhee, Y.W. \& Kim, J.N. (2011). Decarboxylation of naphthenic acid using alkaline earth metal oxide. J. Ind. Eng. Chem. 17(4), 788-793. DOI: 10.1016/J. JIEC.2011.05.024.

16. Quiroga-Becerra, H., Mejia-Miranda, C., Laverde-Cataño, D., Hernandez-López, M. \& Gomez-Sánchez, M. (2012). A kinetic study of esterification of naphthenic acids from a Colombian heavy crude oil. CT\&F - Ciencia, Tecnologia y Futuro 4(5), 21-32. Retrieved December 30, 2015, from http://www. scielo.org.co/scielo.php?pid=S0122-53832012000100002\&scrip$\mathrm{t}=$ sci_arttext

17. Anderson, K., Goodrich, P., Hardacre, C., Hussain, A., Rooney, D. \& Wassell, D. (2013). Removal of naphthenic acids from crude oil using amino acid ionic liquids. Fuel 108, 715-722. DOI: 10.1016/J.FUEL.2013.02.030.

18. Dias, H.P., Gonçalves, G.R., Freitas, J.C., Gomes, A.O., de Castro, E.V. \& Vaz, B.G. et al. (2015). Catalytic decarboxylation of naphthenic acids in crude oils. Fuel 158, 113-121. DOI: 10.1016/J.FUEL.2015.05.016.

19. Shah, S.N., Chellappan, L.K., Gonfa, G., Mutalib, M.I.A., Pilus, R.B.M. \& Bustam, M.A. (2016). Extraction of naphthenic acid from highly acidic oil using phenolate based ionic liquids. Chem. Engine. J. 284, 487-493. DOI: 10.1021/ef502169q.

20. Kulawska, M., Sadlowski, J. \& Skrzypek, J. (2005). Kinetics of the esterification of maleic anhydride with octyl, decyl or dodecyl alcohol over Dowex catalyst. React. Kinet. Catal. Lett. 85(1), 51-56. DOI: 10.1007/s11144-005-0242-1.

21. Tesser, R., Di Serio, M., Guida, M., Natasi, M. \& Santhacesaria, E. (2005). Kinetics of oleic acid esterification with methanol in the presence of triglycerides. Ind. Eng. Chem. Res. 44(21), 7978-7982. DOI: 10.1021/ie050588o.

22. Mandal, P.C., Shiraishi, T., Wahyudiono, Sasaki, M. \& Goto, M. (2011). Kinetics and reaction pathways for heptylbenzene decomposition in supercritical water. J. Chem. Eng. Jpn. 44(7), 486-493. DOI: 10.1252/jcej.10we296.

23. Calvert, J.G. et al. (1981). Formaldehyde and other aldehydes. National Academy Press, Washington D.C., 20-24

24. Ginosar, M., Petkovic, L.M. \& Guillen, D.P. (2011). Thermal Stability of Cyclopentane as an Organic Rankine Cycle Working Fluid Daniel. Energy Fuels 25, 4138-4144. DOI: $10.1021 /$ ef200639r. 